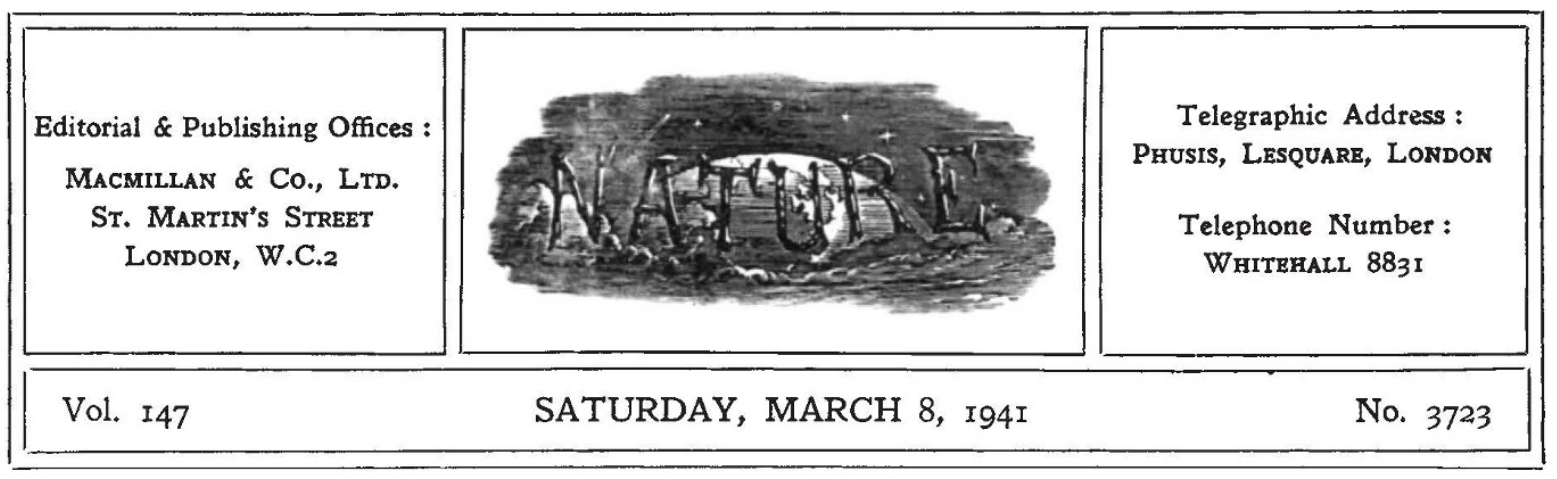

\title{
SCIENCE, POLITICS AND GOVERNMENT
}

$\mathrm{T}$ HE multitudinous ways in which science and its applications impinge on everyday life are apparent, as never before, to every thinking man. That it has required a major disaster in the form of a world war to bring about this realization is not to the credit of civilized people, but the fact should be faced that there is now widespread appreciation of the use-and misuse-which is being made of scientific knowledge. On the credit side must be placed the advances made in medical science as the result of the discovery of new treatments and new synthetic drugs, and the steps which are now being confidently taken to meet the nutritional needs of the nation in the absence of foodstuffs hitherto mainly imported from abroad, quite apart from the general rise in standard of living and increase of amenities to which we have grown accustomed in happier times. On the debit side there is the whole range of horror provided by modern warfare, based on scientific and engineering developments utilized for the destruction of man.

While this much will readily be conceded, there is not so general a concensus of opinion as to the part which science should take in the reconstruction and re-ordering of the world which will follow the end of the War. Correspondence which has been published in NATURE makes this point clear, and the differences of opinion are not only between scientific worker and layman but also among scientific workers themselves. One school of thought believes that science should be a discipline apart from worldly affairs, a disinterested pursuit of truth. Thus Prof. M. Polanyi has protested against a remark in an article in these columns to the effect that science can no longer be regarded as possessing "a peculiar holiness" setting it apart from other social interests. He has been answered by Dr. C. H. Waddington, who puts the case for utilizing scientific method over a wider field than that in which it now functions. Mr. R. H. F. Finlay has pointed to the success attained by chemical and engineering enterprises guided by scientific methods, and asks that science should take control in aspects of government in which it is competent. Dr. V. B. Wigglesworth interprets this as a suggestion that science should actually govern; he asks if that would not be a definite threat to the freedom of scientific research, and states his belief that "the function of science in the national economy . . . is advisory". Elsewhere in this issue (pp. 298, 299), Dr. O. Blüh gives his views on reactions to planning in Central Europe during the past decade, and Dr. E. C. Childs points out some of the difficulties of applying experimental methods in this field.

This great diversity of opinion is evidence that the problem of the relation of science to society is still very much to the fore. It must be approached in a scientific manner; in other words, the data should be gathered, deductions made and tested for consistency and when necessary scrapped, before action is taken. Admittedly, this is no easy task. Scientific men are but human, subject to prejudices like other men, though their training should enable them to recognize more readily when prejudice steps in and reason is put aside.

The fundamental point on which all can agree is that science represents the search for truth, for ever-increasing knowledge of the universe. It is inconceivable that this continuous probing of the secrets of Nature can ever be suppressed, even although circumstances may force it into the background for a while. In due time, some of the facts collected in this way come to have a direct influence on the lives of men, and in this way progressive civilization has been built up. We have 
now reached a stage when the contribution of science to everyday life has become a major one.

But in arriving at the present position, the conditions under which scientific research goes on have changed radically. The days of the natural philosopher pursuing his leisurely inquiries, perhaps alone, perhaps with one or two chosen disciples, have gone. Modern investigations are carried out for the most part in well-equipped laboratories attached to universities or large industrial concerns, while field-work often involves substantial expeditions. Although important discoveries are still made by the individual working with the minimum of apparatus, this method has become the exception. The tempo of research has increased and with this acceleration has come the team of investigators working together on different aspects of the same or allied problems.

Thus research has become to a large extent conditional on financial support, which has come in increasing amounts in recent years from State resources. As the fruits of scientific discovery in the long run lead to a higher standard of living and are of service to the nation as a whole, it is right that the State should contribute funds for this purpose; but this must not be allowed to endanger the freedom of the man of science to seek and to teach the truth. The administrative body can retain general control without allowing political, racial or religious views to influence the course of investigations or to falsify their results. The best method of exerting such control is still an open question, but it is fairly obvious that representative scientific bodies should take a prominent part. An experiment in this direction was the appointment last year of the Scientific Advisory Committee, which reports directly to the War Cabinet. This body, consisting of officers of the Royal Society and of the State research departments, is, of course, a war-time expedient, but it represents the kind of directing influence which should always be present in the Government, not only to formulate policy on the provision of funds for research, but, even more important, to deal with those numerous problems in which science impinges on human welfare both in war-time and in times of peace. Politicians may have special training and aptitude in the art of government, but they cannot be expected to appreciate in full measure the significance of scientific developments, or to foresee the course of events where the application of scientific knowledge is concerned. Here, then, science should have a place in the government of the countrynot to deal with affairs of which it can claim no special knowledge, but with those in which it is particularly competent. It remains for the future to decide the precise manner in which science should be represented in the Government.

Closely entwined in the arguments for and against the participation of science in public affairs, are frequent references to the social responsibilities of science and scientific men. This theme has been discussed many times in these columns. In brief, it comes to this: the scientific worker must seek after truth, but he should not be saddled with the whole responsibility for the misuse often made of it by others. Nevertheless, he should, through his own organizations and individually, press for such appreciation of the true worth of science as would prevent its misuse. It may be argued that it is too much to expect to eliminate the individual, or the State, which would endeavour to exploit discoveries selfishly or without regard for the welfare of mankind, but at least the attempt would be worth while, and it would bring nearer the day when such an individual or State would be outlawed by mankind.

It is perhaps in this wider field of international affairs, paradoxically enough, that the influence of science has produced its most tangible effect. As Prof. A. V. Hill showed in his recent address to the Parliamentary and Scientific Committee (see Nature, March 1, p. 250), international congresses for the discussion of progress in various fields of scientific endeavour have been effective instruments in promoting progress and understanding. Further, as has frequently been emphasized in these columns, the achievements of the scientific and technical services of the League of Nations have marked a noteworthy stage in international collaboration.

Scientific men, working in their own fields, have given a wide significance to the phrase 'science and society'. They have shown that they can rise above political considerations in affairs of the State and internationally, to the lasting benefit of humanity. 'Science' has, indeed, become inseparable from 'society'; one is dependent on the other. On the part which is played by scienceusing the word in its widest sense and including the inquiring and unprejudiced approach which should be characteristic of scientific investigation - -in determining world conditions after the end of the War will depend the stability of international affairs by which alone civilization can flourish. 